\title{
The Innovation of Democratic Education: The Development of Learning Approach Based on the Sutan Syahrir' Thought to Strengthen Students' Democratic Attitude
}

Adi Setiawan', Sariyatun², Deny Tri Ardianto ${ }^{3}$

1Universitas Sebelas Maret, Surakarta, Indonesia

2 Universitas Sebelas Maret, Surakarta, Indonesia

3 Universitas Sebelas Maret, Surakarta, Indonesia

1adi.stawn@gamil.com, ${ }^{2}$ sari_fki_uns@yahoo.co.id, ${ }^{3}$ deny.triardianto@gmail.com

\begin{tabular}{ccc}
\hline Received & Accepted & Published \\
$12 / 09 / 2018$ & $10 / 10 / 2018$ & $31 / 12 / 2018$ \\
\hline
\end{tabular}

\begin{abstract}
In the recent years, the topic of democracy has become important issues for Indonesian society. The designed curriculum and learning practices should be integrated with the thoughts of our founding fathers that reflect the values of democratic attitude. Sutan Syahrir as one of our founding fathers who gave his thoughts in settling the new direction about the democratic state after the Indonesian independence. Sutan Syahrir explains the concept of humanism in the freedom, equality, collectivity, the equality between right and responsibilities. The discussion of Sutan Syahrir's thoughts can be extended to the issues of contemporary education. The authors argue that Sutan Syahrir's thought can be used to develop the innovative learning based on the values of democracy. This article aims to give a conceptual framework of innovative learning about the Sutan Syahrir's thought to improve the students' democratic attitude.
\end{abstract}

Keywords: Sutan Syahrir's thought, learning development, democratic attitude

\begin{abstract}
Abstrak Dalam beberapa tahun terakhir, topik demokrasi telah menjadi isu penting bagi masyarakat Indonesia. Kurikulum yang dirancang dan praktik pembelajaran harus diintegrasikan dengan pemikiran para pendiri kita yang mencerminkan nilai-nilai sikap demokratis. Sutan Syahrir sebagai salah satu bapak pendiri memberikan pemikirannya dalam menetapkan arah baru tentang negara demokratis setelah kemerdekaan Indonesia. Beliau menjelaskan konsep humanisme dalam kebebasan, kesetaraan, kolektivitas, kesetaraan antara hak dan tanggung jawab. Diskusi tentang pemikiran Sutan Syahrir dapat diperluas ke masalah pendidikan kontemporer. Penulis berpendapat bahwa pemikiran Sutan Syahrir dapat digunakan untuk mengembangkan pembelajaran inovatif berdasarkan nilai-nilai demokrasi. Artikel ini bertujuan untuk memberikan kerangka kerja konseptual pembelajaran inovatif tentang pemikiran Sutan Syahrir untuk meningkatkan sikap demokratis siswa.
\end{abstract}

Kata kunci : pemikiran Sutan Sjahrir, pengembangan pembelajaran, sikap demokratis 


\section{INTRODUCTION}

In a broad sense, democracy can be defined as a system of the sovereign state that ensures the freedom and equality of the people to achieve collective welfare. In the context of democracy, freedom can be multifaceted because it can be translated from many perspectives and disciplines. The essential meaning of freedom is not monistic or absolute. The freedom in the democratic sense is confined by a collective agreement and it is set down in a constitutional formulation (Elly Noviati, 2013). Sjahrir in his essay, Renungan dan Perjuangan, defined democracy as a national revolution to go beyond the feudalism, fascism, and chauvinism. Democracy not only relate to the individual right, but it also attains with the individual freedom to control their thought (Sjahrir, 2010). The form of democracy has been influenced by indigenous culture. In the historical process, the form of democracy in Indonesia has experienced some changes from parliamentary democracy (1950 to 1959), Guided Democracy (1959 to 1965), until the era of Democracy based on the values of Pancasila (1999 to present). Contextually, we can conclude that, contextually, the current democratic system in Indonesia is the democracy based on the values of Pancasila or Demokrasi Pancasila, correspond with the national personality (Kaban, 2000).

Democracy in Indonesia encounters with some problems such as power abuse, restraint against freedom of speech. In the New Order era from 1967 to 1998, the democratic values in Indonesia have been degraded by the authoritarian and anti-criticism government. In the 1998s, right after the fall of the New Order government, the values of democracy have been revisited by some politicians, scholars, and people. The people started to get their rights back to give opinions and freedom of assembly. However, polarization and the problem of inequality between majority and minority have occurred. The socio-political turmoil in the presidential election 2014 has made the polarization in the society based on their political interest and religious affiliation. Certainly, the polarization gave bad consequences to the national integration, and in particular degree, it affected the mindset of the younger generation. Education, therefore, becomes an important dimension to invest the democratic values of the younger generation.

The Indonesian educational system is not promoting democratic education as a learning subject, even the national curriculum has mentioned the democratic competence, such as toleration and democratic attitude, as one of the learning objectives of social science and civic education. This circumstance, in the authors' perspective, has confined the prosperity of democratic values among the students. The knowledge and attitude of democracy, whereas, become the important reference for the younger generation to set the future of Indonesia. The founding father had reflected noble values to fight against feudalism, nepotism, and chauvinism. 
Those values can be adopted in the educational field as an exemplary narration to promoting the values of democracy.

Sutan Syahrir, as one of the founding fathers who take a part in the Indonesian independence, had given his thoughts that represented in his action and texts, such as his book, namely Renungan dan Perjuangan, Pemikiran dan Perjuangan, and political pamphlet Perjuangan Kita, which all of his texts described the struggle to achieve independence absolutely through the welfare of society. This can be reconstructed as the direction of the learning process by integrating it into the existing curriculum.

The implementation of Sutan Syahrir's thought, as one of the fathers of the nation, in the learning process to develop democratic education-based learning is one of the right innovations to be applied in classroom learning. This paper specifically discusses on how Sutan Syahrir's thoughts are integrated with learning in the classroom, especially in history lessons. History learning is chosen because the full historical position of meaning, value, and wisdom is a subject that is less desirable. The history learning design is intended to strengthen students' democratic attitudes as capital in community life.

\section{METHOD}

This paper is a study of the literature. Various data are collected through a review of the literature related to the discussion. The literature used is books or journals related to democratic education and Sutan Syahrir' thought.

\section{RESULT AND DISCUSSION}

\section{Democracy for Democratic Society}

Democracy as the principle of liberation from authoritarianism, which was formerly applied by the Persian and Roman kings, becomes a new understanding of a policy decision by emphasizing the person's involvement. Dewey (1903: 193) stated that a modern life means democratic life. Democracy means independent liberation of mind. Furthermore, David Held in Sorensen (2014: 14) suggested that democracy reflects the freedom and equality of life. The people have the same rights and obligations. Freedom is the root of democracy that grows in society. Thus, a democratic government will give a freedom to people. Democracy has long been known and widely applied before it reaches the present form. Democracy had undergone several adjustments in accordance with the spirit of the times and demographics of the population.

The presence of democracy can be traced back to the Greek era. The Greek tried to shape their state, firstly, by answering the question of how a political system must be organized to improve the welfare of their citizens. Furthermore, another form of democracy called as a 
modern democracy arose together with the outbreak of the French revolution to liberate the people from an authoritarian political system, with their slogan: Liberte, Egalite, Fraternity (Soetrisno in Sadiyo, 2003: 8).

A true democracy requires not only good citizens, laws, institutions, or regulations. In its enforcement, democracy requires a democratic attitude that is substantively owned by citizens. Therefore, in order to educate good citizens to ensure the realization of a democratic society, the democratic education is necessary.

Democratic education aims to prepare citizens to think critically and behave democratically through the activity of instilling knowledge and awareness of three things. At least, there are three reasons; first, democracy is a form of community life that guarantees the rights of citizens themselves. Second, democracy is a learning process that cannot simply imitate from other communities. Third, the continuity of democracy depends on the success of transforming democratic values: freedom, equality and justice and loyal to a democratic political system (Zamroni, 2001: 17).

Democracy can be working properly if the welfare, equitable development, economic progress, and public education are guaranteed. The democratic system can be well implemented if the above requirements are not fulfilled. People will think more about their personal interests in making a living rather than thinking about other people's business.

In the Indonesia's history, several democratic systems have changed, from liberal democracy, guided democracy to Pancasila democracy. However, democracy still has not found its ideal form. In the New Order era, the freedom of speech and give a critique seems to be dying due to the authoritarian system of government. Some people who gave critics to the government were arrested without being tried. The New Order government for 32 years has changed the mentality of democracy in Indonesian society. Communities are poorly educated with cheap basic needs, food self-sufficiency. The government's system was filled with corruption, collusion and nepotism. The climax of Indonesian people's disappointment to the government was marked by the fall of President Suharto Indonesia through a new period of reform in which freedom was regained by the people. Public spaces began to be filled with studies and discussions of critical and assumptions for the progress of the nation. A new era of democracy is marked by direct elections in electing the president and vice president. This also drives the discourse on democratic education in learning in educational institutions.

Democracy education becomes crucial at this time considering the problem of freedom of opinion and freedom of expression in the real world as well as the digital world as a result of rapid technological development. The spread of social networking sites that connect many people in an application has made it easy for every human being to connect. At present, there are no more restrictions on communication. Social media has changed the way people think and interact. It brings the some fundamental changes, but there is the potential to keep close. The 
point is that there are negative effects on the communication development. Many people are more concerned to focus their social networks rather than their social environment. It causes a crisis of empathy because they only view the world through social media. On the other hand, the society easily delivers their speech and comments to other people through social media.

The right of freedom of opinion was stated in the 1945 constitutional amendments to article 28 E paragraph 3 which reads "every person has the right to freedom of association, assembly, and express his opinion". Furthermore, the Press Law explained that freedom is given to citizens in conveying information and public opinion through print and electronic media. Freedom of opinion is an important requirement in a country that uses the principle of democracy as a reflection of the people's sovereignty. The government, in this case, must not be anticritical. The implementation of such things is expected to encourage people who think rationally and have further insight. We can set the example of national leaders and their thinkers on how to implement an ideal democratic state, according to the ideals of the nation's founders.

\section{Sutan Syahrir's thoughts on democracy}

Genealogically, the man's thoughts are strongly influenced by his social environment, education and personal experiences. In the case of Sutan Sjahrir, he has a political background as socialist rationalist. Sutan Syahrir got a lot of Dutch education, therefore, his thoughts were influenced by the European ideology and scholars as stated in the history of his life. Sutan Sjahrir was born in Padang Panjang, West Sumatra, on 5 March 1909 and died in Zurich, Switzerland, on 9 April 1966. Sjahrir was an intellectual, pioneering and revolutionary Indonesian independence (Anwar, 2010: 6).

Syahrir received education from basic education to the upper secondary level of education in the Dutch school. Syahrir's father was a chief prosecutor or landraad in Medan and served as advisor to the Deli Sultanate. From his educational background, Syahrir delivered to various foreign books and Dutch novels. From an early age, Syahrir had shown his concern in the world of education. Syahrir was active in the educational movement to eradicate illiteracy of underprivileged families. Syahrir was also the initiator of Jong Indonesia on 20 February 1927 which was the driving force in the implementation of the youth pledge in 28 October 1928. In the era of revolutionary, Syahrir contributed a lot to the proclamation process of Indonesian independence. This also ultimately led him to become the first and the second Prime Minister of Indonesia during the Republic of Indonesia.

During his tenure as prime minister, through the policies he made, Sutan Syahrir formed a multi-party cabinet and structure. Syahrir wanted to realize the sovereign democracy through democratic political system. The appointment of Syahrir to become prime minister was not without reason. His firm establishment to stand against the Japanese had made him easy to be 
seen by the other politicians or foreign ambassador as the anti fascist. Kholid O. Santosa, in his book, Tan Malaka \& Sjahrir dalam Masa Krisis (Santosa, 2015), perceived Sjahrir's policy to establish a multi-party parliamentary government system was a strategic decision. A democratic multiparty system enables the active participation from pluralistic society. The policy can accommodate a variety of different political groups and affiliations in Indonesia. Sjahrir's desire for freedom was implemented in the policies that he made. The experience of exile had brought a lot of meaning to him. He becomes closer the people, and at the same moment, the people needed many intellectuals to support the independence revolution movements.

Syahrir prioritized a peace rather than a violence. His western educational background had shaped the anti-fascist socialist thinking, but it was not part of the communists who created a revolution with physical revolution and bloodshed. The desired revolution was to create the idea that the revolution must be accompanied by democratization of the state and citizens (Sjahrir, 2010: 19).

Sutan Syahrir poured his thoughts in writing. Much of his work is used as a reference in studying about how the concept of the democratic state. His works include Out of Exile, Our Struggle, Reflection and Struggle, Indonesische Overpeinzingen, and Mind and Struggle. At the time of the independence revolution, Sutan Syahrir's text became a controversy. As a humanist leftist, Syahrir put forward a diplomatic method by seeking international recognition and negotiating with the Dutch. These things are the basis of Syahrir's revolution in democracy. Robertus Robert, who served as Secretary General of the Democratic Education Association in Tempo: The Big Role of Little Bung (Tempo, 2010: 4), has revealed that Syahrir is the first person to propose a dual view on Indonesian politic. Syahrir decided on social hatred by pouring the idea of humanism and universality. This is in accordance with one of the foundations of democracy, namely equality and equality.

Several ideas on the Syahrir's (2010) thoughts regarding the implementation of democratic states are described below:

\section{Education}

Education relates to the human mindset and human intelligentsia. It becomes the capital to build a critical thinking and broad-mindedness. Without education, the public will not understand how to become a good and responsible citizen. Education is an important key in shaping democratic society. Syahrir has manifested his mind by taking part in various activities during his education. His role in illiterate eradication and other social activities for the poor were a big exception in the world of education. Syahrir assumed that democratic society might be built from the political education of the rulers. This certainly can be an example for community life. 


\section{Social welfare}

In the eyes' of Syahrir, the workers, peasants, and people or commonly called as Marhaen, were the key to the progress of a nation. Equity and active participation of the community to participate to advance the nation's economy will make the country's economy stronger. Natural wealth and resources must be enjoyed by all people without exception. The task of the government to manage the best natural resources available for social welfare.

The thought and role of Sutan Syahrir can become a reference to determine the ideal direction of democratic education. Even though Syahrir's thoughts seem leftist, the important point is the hope that the state must be built based on people's sovereignty and mutual welfare.

\section{Development of democratic education}

Dealing with democratic values in interacting with each other was minimized by immoral actions such as bullying, persecution, and intimidation. Democratic values should be applied to students to shape their democratic attitude as a good citizens so that they understand their rights and responsibilities in the community. This is also reinforced by Dewey ideas of "being able to" experience "a fundamental aspect of schooling. According to Dewey, teaching and learning where it is possible to experience is central to democratic schools, which implies setting the premises for what knowledge to learn "(Dewey, 1903: 3).

The implementation of democracy requires a democratic attitude from all levels of its citizens. Therefore, every citizen has a responsibility to implement a democratic attitude in their daily activities (Harahap s, 2017: 268). Definitively, a democratic attitude is the actualization of a democratic concept at the individual level. Democratic attitudes are manifestations of individuals who instill democratic concepts and values in their lives. Democratic attitude is a reflection of the implementation of the values contained in democracy itself. The attitude of democracy is the achievement of the ultimate goal of applying democracy in a region by its inhabitants. Democratic attitudes are also one of the results of learning democratic education (Sariyatun, et al, 2018: 114).

The democratic attitude, certainly, cannot be separated from the synergy between the process of good moral, value education, and the quality educators. Definitively, according to Mustari (2014: 137) democratic attitude is a way of thinking as well as acting that assesses the rights and responsibilities of others. It can be concluded here that what becomes the benchmark in a democratic attitude is the freedom, equality and tolerance. Tolerance becomes important in planting the democratic attitude because without tolerance the community cannot speak widely and freely. This circumstance can create a possibilities and difficulties in the practice of democratic attitudes that depend on the willingness of the community to speak widely and participate, that Amy Gutman calls as a deliberative democracy (Sahal, et al, 2018: 120). 
Alternatively, John Dewey (1903) recommended organizing all school activities as a miniature of democracy. He believed that the students can participate in developing a social system, thinking experiences, and learning how to apply scientific methods to improve human society. Therefore, attitudes and the implementation of democratic values are good not only because it is implemented by teachers in the classroom, but also familiarized through the culture and environment of the school.

Democratic culture in the school environment needs to be supported by the development of democratic education through learning in the classroom. This can be an alternative way to remember that democracy education is not a stand-alone scientific discipline. Democratic education is included in the history subject. However, the establishment of a democratic attitude is not only the task of certain subjects, but it attains all subjects through habituation in the classroom. Historical subjects that contain of learning material about the role of Sutan Syahrir in the national level are revealed. Historical learning is no longer limited to understanding and knowing historical events. More than that, historical learning should be perceived as a value and moral education from the activity of analyzing past events by taking the meaning of the events. Mastery of competencies about historical awareness and imitating attitudes and thoughts of leaders can be implemented in the development of innovative learning and teaching materials. The development of teaching materials will be more practical and effective in accordance with the current need of the millennial generation with digital book technology approaches.

The role of educators is to highlight and promote the figure of Sutan Syahrir's as one of the heroes to students. Moreover, the meaningful learning must involve an active students' activity. The implementation of a learning model that demands the active role of students is certainly needed. Group Investigation (GI) model can be posited as one of the models that can be used in history learning in class. GI learning models combine the structure of teaching strategies with a dynamic democratic process based on inquiry education (Joyce, B., Weil, M., 2003: 278). Therefore, with the existence of innovative models and teaching materials, educators must be separated from the old paradigm and methods that are less relevant to the current condition of students. History teachers must be separated from the old paradigm of learning that places students as passive individuals. Through discussion and group learning, the students can get to know more about how a democratic process. They will be more easily accept and respect for others opinions and differences.

\section{CONCLUSION}

Democracy is a system that emphasizes the people's sovereignty as the main idea of its implementation. Democracy is always having its own form. The historical and cultural 
background of the society influences the form of democracy. In the context of Indonesian democracy, the democracy Pancasila is used based on the values of Pancasila by upholding the noble values of the nation. Although Indonesia has experienced several changes, from parliamentary democracy, guided democracy to democracy Pancasila.

The implementation of Democracy does not always going well. Technological advances that gave birth to social media trends became a new discourse. The problem lies about how to the education fortify students as the nation's young generation in the face of the development of thought technology and hegemony. Students must be critical and broad-minded to be able to take part in organizing democracy in Indonesia

An appropriate integrated democratic education can give an impact on the quality of students' democratic attitudes. Democratic education must be developed in accordance with the spirit of the times. One of the alternatives of democratic education is to be held through the historical learning process of with the learning subject of Sutan Syahrir's thought. In more details, the learning material about the Indonesian Youth Pledge, in which Syahrir took part and raised his mind about the idea and purpose of the nation towards independence, can be used as an example that since the early of national movement the Indonesian youth had provoked a democratic process.

\section{REFERENCES}

Anwar, R. (2010). Sutan Sjahrir: Demokrat Sejati, Pejuang Kemanusiaan. Jakarta: PT. Kompas Media Nusantara KITLV Press.

Dewey, J. (1903). Democracy in Education. The elementary school Teacher. University of Chicago Press, Vol.4(No.4), 193-204.

Elly Noviati, C. (2013). Demokrasi dan Sistem Pemerintahan. Jurnal Konstitusi.

Harahap s, S. (2017). Pendidikan Karakter Dalam Menumbuhkan Sikap Demokratis Melalui Penerapan Model Pembelajaran Kooperatif Tipe Grub Investigation. Prosiding Seminar Nasional Tahunan Fakultas Ilmu Sosial Universitas Negeri Medan, 1(1), 268-272.

Joyce, B., Weil, M., \& C. (2003). Models of Teaching. United State: Allyn \& Bacon.

Kaban, R. (2000). Perkembangan Demokrasi Di Indonesia. Perspektif.

Mustari, M. (2014). Nilai Karakter Refleksi Untuk Pendidikan. Jakarta: Raja Grafindo Persada.

Sahal, M., Musadad, A. A., \& Akhyar, M. (2018). Tolerance in Multicultural Education: A Theoritical Consept. International Journal of Multicultural and Multireligius Understanding, Vol.5(No.4), 155-122.

Santosa, K. O. (2015). Tan Malaka \& Sjahrir Dalam Kemelut Sejarah. Bandung: Sega Arsy.

Sariyatun, Joebagio, H., \& Sumardjoko, B. (2018). Proliferation of democratic education in Indonesia: The influence measurement of tolerance, multiculturalism, and historical 
awareness on the democratic attitude. New Educational Review, 52(2), 112-123. https://doi.org/10.15804/tner.2018.52.2.09

Sjahrir, S. (2010). Perjuangan Kita. (B. Basuki, Ed.) (Edisi Eboo). Anjinggalak.tk. Tempo. (2010). “Sjahrir .” 